UDK: 341.49

Pregledni rad

\title{
EXPANDING JURISDICTION OF THE INTERNATIONAL CRIMINAL COURTS: COHERENCE OR CHAOS ${ }^{1}$
}

\author{
Tijana Surlan ${ }^{2}$ \\ Academy of Criminalistic and Police Studies, Belgrade
}

Summary: Within the present paper a new phenomenon has been elaborated - a phenomenon of expanding jurisdiction of the present international criminal courts. At the moment there are two ad hoc International Criminal Tribunals, one permanent International Criminal Court and several hybrid and internationalized international criminal courts. Ad hoc Tribunals are in the phase of transformation into the UN Mechanism for the International Criminal Tribunals, as a completely new forum, thus expanding Tribunals jurisdiction in a new direction. As for the International Criminal Court, desirable mode of its expanding is through the increase of its member states, in the overall list of member-states. What is happening in reality is that states are approaching ad hoc at the ICC's docket, as the situation directs them. Tendency in the realm of the international criminal judiciary is that creation of new international criminal courts is expected, although not warmly accepted. With the multiple international criminal courts existing, in the same ratione materiae jurisdiction, it is highly expected that the overlaps will occur as well as the expanding of the jurisdiction that is beyond the usual terms of norms interpretation. The focus of this paper is on a dilemma whether such a situation will provoke coherence or chaos.

1 This paper is the result of the research project: "Crime in Serbia and instruments of state response", which is financed and carried out by the Academy of Criminalistic and Police Studies, Belgrade - the cycle of scientific projects 2015-2019.

2 Associate Professor of International Public Law, tijana.surlan@kpa.edu.rs 
Keywords: Jurisdiction, Expanding, ad hoc International Criminal Tribunal for former Yugoslavia, ad hoc International Criminal Tribunal for Rwanda, UN Mechanism for the International Criminal Tribunals, International Criminal Court

\section{Introduction}

There is an overwhelming idea that above all institutions and organs the judiciary must keep impartiality. Impartiality and independence are conditio sine qua non of each and every judicial body and proceeding. ${ }^{3}$ Yet, for a court to achieve the virtue of impartiality and independence, its structure should be firm and jurisdiction clearly defined. On the other hand, when it comes to the analysis of the achievements of international criminal courts, it is usually stated that it is exactly their impartiality that was challenged. ${ }^{4}$ Where does it come from? Is it just a reflection of dissatisfaction with the outcome of the proceeding or it rests on concrete indicators?

The purpose of this paper is not to analyze all possible attacks on court's impartiality, but to keep focus on one aspect - the aspect of jurisdiction. At the moment there are quite a number of international criminal courts, with various backgrounds, purposes and structures. A number of courts could easily create competing jurisdiction among them. ${ }^{5}$ Yet again, it can actualize jurisdiction of each and every international criminal court, its scope and adaptability to change. ${ }^{6}$

Before we focus on two examples with immense importance for our country, it would be convenient at least to name all international criminal courts acting at the moment. Chronologically, the first international criminal court created after Nuremberg and Tokyo international military tribunals, was ad hoc International Criminal Tribunal for the former Yugoslavia, founded in 1993. It was created by the Security Council Resolution, acting on Chapter VII of the UN Charter. ${ }^{7}$ While all ex-Yu countries protested on the occasion

3 Т. Шурлан, Место Гаагских конференций (1899 и 1907 гг.) в развитии международного права и международных отношений, у: Смолина М.Б., Залеский К.А. (ред.), Накануне Великой войны: Россия и мир - Сборник докладов и статей, Москва 2014, pp. 119-141.

4S. Katzenstein, In the Shadow of Crisis: The Creation of International Courts in the Twentieth Century, Harvard International Law Journal, Vol. 55, number 1, 2014, pp. 151-178.

5 R.Dicker, The International Criminal Court and Double Standards of International Justice, u:C.Stahn, The Law and Practice of the International Criminal Court, Oxford University Press, 2015, str.3-11.

6 B. Broomhall, International Justice and International Criminal Court: Between Sovereignty and the Rule of Law, Oxford, 2003.

7 UN Security Council Resolution 827 (1993) of 25 May 1993; Sunga L.S., The Emerging 
of Tribunal foundation by the UN SC Resolution, Rwanda asked the UN for creation of the similar tribunal for the purpose of prosecuting the perpetrators of immense genocide which occurred in Rwanda. ${ }^{8}$ Thus, the Security Council adopted yet another Resolution and created another ad hoc tribunal - ad hoc Tribunal for Rwanda in 1994. ${ }^{9}$ It is worth mentioning that these fundamental changes in the structure of international judiciary came after fifty-year work of the General Assembly and the International Law Commission on drafting of the Statute for an International Criminal Court. ${ }^{10}$

\section{Competing Jurisdiction between ICTY, ICTR and the UN Mechanism for International Criminal Tribunals}

In both ad hoc Tribunals Statutes time frame was not set in the definite framework. While the commencement of the Tribunals work was clear and evident, closely connected to the exact period of crime perpetration, finalization of their work was not defined. ${ }^{11}$ It came out as a surprise for the entire international community that the work of the Tribunals appeared to be extended above the expected time frame. One of the main problems for the future functioning of the Tribunals is in the aspect of financing of their prolonged work. With the experience in the Tribunal's structure and organization, the UN created another model of international courts - hybrid courts, mixing international and domestic stuff, using the infrastructure of

System of International Criminal Law: Developments in Codification and Implementation, Kluwer Law International, 1997.

8 W.A. Schabas, The UN International Criminal Tribunals - the former Yugoslavia, Rwanda and Sierra Leone, Cambridge University Press, 2006, str.12;L. van den Herik, The Contribution of the Rwanda to the Development of International Law, Martinus Nijhoff Publishers, 2005, str.7; L.N. Sadat, The International Criminal Court and the Transformation of International Law, in: Sadat L.N., Scharf M.P. (ed.), The Theory and Practice of International Criminal Law. Essays in Honour of M. Cherif Bassiouni, Martinus Nijhoff Publishers, 2008, str.309-324..

9 UN Security Council resolution 955 (1994) of 8 November 1994

10 A. Cassese, From Nuremberg to Rome: International Military Tribunals to the International Criminal Court, u: Antonio Cassese, Paola Gaeta, John R.W.D. Jones (eds.), The Rome Statute of the International Criminal Court: A Commentary, Volume I, Oxford University Press, 2002.

11 Jurisdiction ratione temporis was defined in the Statute of the International Criminal Tribunal in Article 1 - Competence of the International Tribunal as "serious violations of international humanitarian law committed on the territory of the former Yugoslavia since 1991" and in Article 8 - Territorial and temporal jurisdiction "temporal jurisdiction of the International Tribunal shall extend to a period beginning on 1 January 1991"; the Statute of the International Criminal Tribunal for Rwanda provided in Article 1 that jurisdiction of the Court is over serious violation of the International Humanitarian Law that occurred in the period between 1 January 1994 and 31 December 1994. 
already existing domestic courts, applying mixed law - international and national. New model of courts - hybrid courts happened to be easier for managing and less financially demanding. ${ }^{12}$

On the other hand, the UN was looking for the exit from the demanding position of the Tribunals. It thus created a new form of court under the title - the UN International Residual Mechanism for Criminal Tribunals, shorter version the UN Mechanism for International Criminal Tribunals. As the outcome of this decision at the moment there are three parallel institutions. Both ad hoc Tribunals - ad hoc International Criminal Tribunal for the former Yugoslavia, ad hoc International Criminal Tribunal for Rwanda and the UN Mechanism for the International Criminal Tribunals.

New situation raised new issues. One of them is - are we witnessing legal or illegal action? Is it lege artis to create another judicial body while primary judicial bodies still act and proceed? Is jurisdiction of a new court breaching traditional fundamental principles lis pendens, how does it correspond with the principle of res judicata? Are these three institutions proceeding in coherent jurisdiction or in competing jurisdiction? And finally, is competition among them decisional or jurisdictional competition?

With the purpose to analyze each aspect, formulated in a manner of a question, it is inevitable to look into the basic documents setting new international body in criminal matters.

Technically the UN Mechanism for International Criminal Tribunals (further on: Mechanism) was created by the UN Security Council, adopting the Resolution and within the Resolution annexed the Statute of the International Residual Mechanism for Criminal Tribunals. ${ }^{13}$ Prior to the adoption of the mentioned Resolution, the Security Council started developing "completion strategy". ${ }^{14}$ In several resolutions adopted by the Security Council during 2003 and 2004, the Tribunals were suggested to complete investigations by the end of 2004, all trial activities by the end of 2008 and to complete all work in $2010 .{ }^{15}$ Since the time line has not been met the Security Council ordered a new deadline, setting it to the end of 2014. The task set to the Tribunals was to prepare full closure, to arrange transition to the Mechanism and to organize effective teams to prolong with the cases.

12 B. Ivanišević, The War Crimes Chamber in Bosnia and Herzegovina: From Hybrid to Domestic Court, International Center for Transitional Justice, 2008.; S.M.H. Nouwen, "Hybrid courts": The hybrid category of a new type of international criminal courts, Utrecht Law Review,Vol.2, Issue 2, 2006; Lj. Dapčević Marković, Međunarodni krivični tribunal, Bezbednost,God.38, br.6, 1996, pp.722-730.

13 UN Security Council Resolution 1966 (2010) of 22 December 2010, S/RES/1966 (2010), by a vote of 14 to none and abstention from Russian Federation.

$14 \mathrm{Ibid}$, par. 1.

15 UN Security Council Resolutions 1503 (2003) of 28 August 2003 and 1534 (2004) of 26 March 2004. 
The general idea on the organization of the Mechanism was to create a smaller body, temporary body, with small number of stuff, both judges and secretariat. Nevertheless, it is inevitable that although unified in one body previous ad hoc Tribunals should be separated and presented in two branches. Time for the commencement of its work was set on 1 July 2012 - the branch for the ICTR and 1 July 2013 - the branch for the ICTY. It is also provided that the Mechanism should operate for the period of four years, with the assumption that all necessary procedures will be finalized. ${ }^{16}$

Although the Mechanism presents new jurisdictional body, set by the Security Council under Chapter VII of the UN Charter, in one domain it continues the work of the Tribunals. In the other domain the Security Council created new rules, within the new Statute and in the third domain the Secretary General was obliged to adopt the Rules of Procedure and Evidence for the new Court. Mainly, primary jurisdiction ratione materiae was transferred to the Mechanism. New Statute did not come out with new catalogue of crimes or with renewed, redefined definitions of the existing crimes. Thus, the hard core of jurisdiction did stay untouched. Also, the Mechanism is obliged to respect all international agreements concluded by the UN considering both ad hoc Tribunals, which are still in force. They are considered to be "in force" for the Mechanism, automatically.

Resolution itself is drafted in obligatory tone. It poses obligation on states to cooperate fully with the Mechanism in all possible aspects of its work "without undue delay $[\ldots]$ in the location, arrest, detention, surrender and transfer of accused persons". ${ }^{17}$ Specifically it demands States where fugitives are suspected to be "to intensify cooperation with and render all necessary assistance to the Tribunals and the Mechanism, as appropriate, in particular to achieve the arrest and surrender of all remaining fugitives as soon as possible". ${ }^{18}$

Competence of the Mechanism is defined in Article 1 of its Statute. It is provided that the Mechanism shall continue the material, territorial, temporal and personal jurisdiction of the ICTY and the ICTR, as well as the rights and obligations of both courts subject to the provision of the new Statute. Although it could be presumed that the main competence of the Mechanism will be appeal procedures, it is not stipulated as such. On the contrary, the Mechanism is empowered with the right to prosecute in accordance with the new Statute. It is not, on the other hand, empowered with the right to issue any new indictment.

According to its powers, the Mechanism consists of Trial Chamber and the Appeals Chamber common to the branches of both ad hoc Tribunals (Article 4). It has the Prosecutor and Registry, common to both branches as well.

16 Ibid, par.17.

17 Ibid, par.8.

18 Ibid, par.10. 
The Mechanism's jurisdiction is created as the concurrent jurisdiction. Such a principle is highly arguable in terms of procedural law. In the relationship with the national courts, yet, it has primary jurisdiction and it is supplied with the right to formally request national courts to defer to its competence. This stipulation is common to both ad hoc Tribunals Statutes and rests on objective incapability of national judiciary systems to proceed. For all countries that the Mechanism has territorial jurisdiction over, it is no longer the situation. Thus, the provision as stated does not rest on the solid foundations. That such reasoning is justified confirms Article 6, since it empowered the Mechanism to refer cases to national jurisdictions. In such a case the Mechanism is thoroughly involved further on with the case, since it is obliged and entitled to monitor cases referred to national judiciary (Article 6).

Yet another set of unusual and new provisions appears under the section on judges. Judges form roster, not chamber or department, in the total amount of 25. Judges do not form stable composition present at the seat of the court. On the contrary, their functions do not request their presence at the court's premises. Judicial function "may be exercised remotely, away from the seats of the branches of the Mechanism" (Article 8). Another, big change is in the domain of the official languages. Mechanism is about to use only English and French, as all other international courts, and not BHS as previously in the work of the ICTY. Although this novelty could be marked as symbolical and in the overall spirit of international law, it is more than that for the accused. Changing the use of languages certainly shows the changes in the approach.

It is supposed that both ad hoc Tribunals will transfer their jurisdictions willingly. Thus, no rivalry will occur. Yet again, Tribunals do present one part in the proceedings. It is, thus, to be expected that the accused through their defense could challenge the changes in jurisdiction.

At the moment, there is yet another court in the phase of creation - a court dealing with war crimes that occurred at the territory of Kosovo in the period 1998-2000.

An idea to form special criminal court for the crimes committed at the territory of Kosovo is as old as the United Nations Mission on Kosovo (UNMIK). The first proposal was to establish the Kosovo War and Ethnic Crimes Court, similar to the ICTY. It would have primacy over domestic courts, which would also be authorized to prosecute international crime perpetrators. Although the foundation of the court has gone through the first preparation phase, at the end it was not created. One of the reasons for such a decision was concurrent jurisdiction with the ICTY.

The need to establish a special international criminal court for the international crimes perpetrated at Kosovo emerged once again in the period 2010-2014. The fact that the crimes which were committed at Kosovo were 
not prosecuted, either by the ICTY or the Kosovo courts, appeared due to the Council of Europe report completed by Dick Marty. ${ }^{19}$ While exploring the Kosovo situation, Dick Marty discovered the facts on organ trafficking connected to the war crimes that occurred on the territory of Kosovo and north Albania during the period 1998-2000. ${ }^{20}$ In his findings a number of Kosovo Liberation Army (KLA) members were accused of abduction and forced organ removal. It is worth mentioning that such information was not completely new, only presented in more detailed manner. Karla Del Ponte, the former Prosecutor at the ICTY was aware of these crimes. ${ }^{21}$ Yet again, her stand was that the ICTY could not establish jurisdiction since organs were removed from human bodies on the territory of Albania, where Albania was not under the jurisdiction of the ICTY.22

Since Dick Marty's Report did not present the document suitable to raise indictment in terms of criminal investigation, the European Union established an autonomous investigative body based outside of Kosovo, namely the Special Investigative Task Force (SITF). An American investigator Clint Williamson, though, was named the first chief prosecutor of that EU body.

Williamson produced his report on July 2014, stating that he established enough evidence for the indictments against the former senior KLA officials. His findings were on organized campaign of abduction, illegal detentions, unlawful killings and sexual violence directed against Serbs and Roma mainly. The findings on forced organ removal were largely consistent with Dick Marty's Report, but yet again there were not enough evidence to merit indictment for that crime.

The final and the most important impact of Williamson's Report is the urge to create a special court. Since the period when the Report was delivered up to now, several versions on the future court were on the table. In the first days after the Report, it was clear that a court to come should be international criminal court, probably in the version of hybrid international criminal court, seated outside Kosovo. Even preliminary negotiations were carried out with the Government of the Netherlands. As the time was passing more ideas and propositions were arising. The last version that could be heard through media is the strong belief that such a court should be organized in Kosovo, applying the

19 T. Šurlan T., Transplantacija i trgovina ljudskim organima, tkivima i ćelijama međunarodnopravni i nacionalnopravni normativni okvir, Fondacija Centar za javno pravo, http://www.fcjp.ba/templates/ja_avian_ii_d/images/green/Tijana_Surlan.pdf 20 Council of Europe, Parliamentary Assembly, Investigation of allegations of inhuman treatment of people and illicit trafficking of human organs in Kosovo, Resolution 1872, 25 January 2011.

21 C. del Ponte, La caccia: Io e i criminali di guerra, 2008 - http://en.wikipedia.org/wiki/ The_Hunt:_Me_and_War_criminals

22 T. Šurlan., Oduzimanje organa kao actus reus međunarodnih krivičnih dela, Strani pravni život, 2/2014, pp.57-76. 
Kosovo law. Although such a court should operate within the Kosovo justice system, it should appoint international judges and prosecutors, acquiring thus the status of the hybrid international court. EU member states such as Spain have been reluctant to endorse a court that would recognize Kosovo as a state and implement its laws because they reject Kosovo's secession. Greece, Slovakia, Romania and Cyprus also refuse to recognize Kosovo's secession from Serbia.

During the summer of 2015 the creation of the Special Court was voted in the so called Kosovo Parliament, after several unsuccessful attempts. The Statute or any other founding legal act has not been made public so far, thus not allowing any further comment on it. On the other hand, the creation of the new judicial body in the field of the International Criminal Law itself does offer material for conclusion that contemporary international community is in the state of chaos, when it comes to international criminal judiciary. It was not necessary to create a new organ; ICTY had jurisdiction over all crimes that occurred on the territory of the former Yugoslavia since 1991. Ground to refuse jurisdiction over crimes that the Report of Council of Europe representative Dick Marty covered, namely organ trafficking was found in the fact that it was perpetrated on the territory of the northern Albania, since the jurisdiction ratione loci covers only the crimes perpetrated on the territory of the former Yugoslavia. This explanation, as much as can be understood, is not legally coherent. Shortcomings in this syllogism rest on the fact that was not elaborated, and that is that victims who had their organs removed were kidnaped on the territory of Kosovo, during the civil war, transferred to the North of Albania, where the crimes were finally executed.

\section{Expanding Jurisdiction of the International Criminal Court}

Creation of the International Criminal Court (ICC) was welcomed warmly in the international community. It was created shortly after ad hoc Tribunals and the truth is that it is very likely that the ICC would not have been created if there were no ad hoc Tribunals. ${ }^{23}$ Speaking in terms of morality, there was no ground not to create it. The Court was created as an independent body, not being the part of the UN system, yet closely related to it. ${ }^{24}$

23 Statute adopted at the Conference in Rome on $17^{\text {th }}$ July 1998, entered in force on the $1^{\text {st }}$ July 2002.

24 L.N. Sadat, The International Criminal court and the Transformation of International Law, in: Sadat L.N., Scharf M.P. (ed.), The Theory and Practice of International Criminal Law. Essays in Honour of M. Cherif Bassiouni, Martinus Nijhoff Publishers, 2008; Ž. Jović, Mirovne misije UN i globalizacija, Bezbednost, Godina LVI, br. 1, 2014, str.104-121. 
It is worth mentioning that decades have passed since the UN General Assembly adopted the resolution underlining the necessity for an international criminal court. ${ }^{25}$ The UN Security Council acted much more operational, when it comes to creation of tribunals, notwithstanding the issues on legality of such an act. Thus, at the end of the previous century there were two functional ad hoc Tribunals created by the UN Security Council and one permanent International Criminal Court created through the negotiating process, in the form of an international treaty, under the auspices of the UN General Assembly. Thus, at the moment of the ICC's creation, two international criminal courts were already functioning. Their jurisdiction could not overlap primarily due to the principle of jurisdiction ratione temporis. Temporal jurisdiction of the ICC was set pro futuro. In Article 11 (ICC Statute) it was stipulated that "The Court has jurisdiction only with respect to crimes committed after the entry into force of this Statute".

Besides, the jurisdiction of the ICC is set as complementary to the national courts jurisdictions (Article 1 of the Statute). ${ }^{26}$ Such a provision provides completely opposite approach comparing to the Statutes of ad hoc Tribunals. Both cited provisions provided no overlap between ad hoc Tribunals and the ICC.

The founding idea through the process of the permanent court creation was to create an international criminal court that would be permanent and universal. The ICC is permanent no doubt, but is it universal? The ICC Statute at the moment has 123 state-parties. States such as the USA, Israel, Russia, Ukraine, China, India, Iraq, Iran, Libya, Syria and Pakistan are missing. This is exactly the turning point - has the Court that has been created fulfilled the goals of its establishment? Do we have a universal court or not? And what is its future?

Let us look once again into the jurisdiction provisions. ${ }^{27}$ Besides jurisdiction ratione temporis the Court's jurisdiction is featured by jurisdictions ratione materiae, ratione loci and ratione personae. ${ }^{28}$ The principle of jurisdiction ratione personae provides that the Court will have the power to prosecute citizens of state parties; ratione loci principle provides that the Court will have the power to prosecute the crimes perpetrated on the territory of state parties. And plus, there is a specially designed provision recognizing the importance

25 UN General Assembly Resolution95 (I) of 11 december 1946.; M.C. Bassiouni, A Draft International Criminal Code and Draft Statute for an International Criminal Tribunal, Martinus Nijhoff Publishers, 1987

26 W.A. Schabas, An Introduction to the International Criminal Court, Cambridge University Press, 2001, pp.12-17.

27 T. Surlan, Princip ne bis in idem u Rimskom Statutu, NBP - Nauka, bezbednost policija, Vol. IX, No. 1, 2004, pp. 93-115

28 T. Šurlan, Princip univerzalne krivične nadležnosti, NBP - Nauka, bezbednost policija, Vol. 2011, XVI, No.2, str.101-116. 
of the UN Security Council's role for international peace and security, granting it with the power to refer a situation occurring in the non-state party. ${ }^{29}$

The ICC currently prosecutes 22 cases, arising from 9 situations. All of them occurred at the African continent. This fact has been the ground for severe criticism of the Court's work, implying racism, discrimination and frustrations for African states. ${ }^{30}$

Great novelty is that besides the mentioned cases, the ICC's Office of the Prosecutor (OTP), at the moment conducts preliminary examination in situations of Afghanistan, Georgia, Guinea, Columbia, Honduras, Korea and Nigeria. Thus, for the first time the scope of work has been expanded to Europe, Asia, and America. All these mentioned expansions do come under the institute of compliance and do not present an example for the expanding of the jurisdiction as the main focus of this article. Yet, there are several cases that illustrate expanding of the Courts jurisdiction.

New investigation concerns the crimes committed in Ukraine in the recent past. This state is not a member-state to the ICC. It is worth mentioning that Ukraine signed the Rome Statute in 2000, but couldn't ratify it since the Ukraine Constitutional Court found that such a treaty is incompatible with the Ukraine's Constitution. Nevertheless, Ukraine showed its interest for cooperation with the ICC again, accepting its jurisdiction over the alleged crimes committed in the period 21 November 2013 - 22 February $2014 .^{31}$ This period is marked by Maidan Square demonstrations and the use of force by the then Government of Ukraine. This time there were no references to the findings of the Constitutional Court, either by the Ukraine representatives, or the Court's officials. What happened in this situation is establishing the limited jurisdiction of the Court, which can be highly criticized in terms of undermining the Court's impartiality and universality. The arrangement between the Court and Ukraine prevented expanding of its jurisdiction to the overall civil war period. This is the first time that a non-state party made a self-referral, concentrating it exclusively to one person, thus leaving open wide space for speculations on the real interests of Ukraine in this potential proceedings.

29 T. Surlan, Influence of the Security Council on the Jurisdiction of the International Criminal Court and Possible Revision of the Article 16, in: Thematic Conference Proceedings of International Signifacance, Archibald Reiss Days, Vol. II, Belgrade, 2011, pp. 469-480.

30 T. Murithi, The African Union and the International Criminal Court: An Embattled Relationship?, Institute for Justice and Reconciliation, 2013, https://www.africaportal.org/ dspace/articles/african-union-and-international-criminal-court-embattled-relationship; A. Afagbegee, The International Criminal Courts relation with Africa: An Unfair Bias?, Pan-African Voices for Freedom and Justice, 2014. http://www.pambazuka.net/en/ category.php/features/91998

31 ICC, Declaration by Ukraine lodged under article 12(3) of the Rome Statute, 9 April 2014, ICC-CPI-20140417-PR997. 
Another novelty for the Court is enrollment of the new member - Palestine. Palestine formally became member-state to the Rome Statute on 1 April 2015. In January 2015, though, it lodged a declaration accepting jurisdiction of the ICC over the alleged crimes committed "in the occupied Palestinian territory, including East Jerusalem, since June 13, 2014". ${ }^{32}$ The reason for submitting the declaration at almost the same time as ratifying the Statute is (i) rationae temporis jurisdiction of the Court, and (ii) Palestinian status as a state. Previously, Palestine lodged declaration in 2009 initiating preliminary examination. Yet, its declaration was not accepted since at that time Palestinian status as a state was not clear. After Palestine gained status of non-member observer state in the UN, the ICC decided to accept its declaration and enroll Palestine as a new member-state.

Some other information, concerning further preliminary examinations, are also important to be mentioned here. The Prosecutor Fatou Bensouda received on 10 January 2014 the information alleging the responsibility of high British officials, members of armed forces, for war crimes in Iraq, in the period between 2003 and 2008. ${ }^{33}$ The dossier was presented by Public Interest Lawyers (PIL) and the European Centre for Constitutional and Human Rights (ECCHR), citing more than 400 individual cases, representing "thousands of allegations of mistreatment amounting to war crimes of torture or cruel, inhuman or degrading treatment". The Prosecutors decided to reopen a preliminary examination of the situation in Iraq. ${ }^{34}$ Such decision has been welcomed by human rights activists and supporters of international criminal justice, as a step that has potential to reaffirm the Court's role in the international community.

The previous example, although registered as "situation in Iraq", grounds jurisdiction on the British citizenship of perpetrators, since Great Britain is a member-state to the Statute of the ICC.

Another interesting issue emerged before the ICC considers the atrocities committed by the members of the ISIS (Islamic State of Iraq and Syria). The OTP has been informed in various forms and by various actors on alleged different international crimes. Thus, the Prosecutor issued the statement explaining that the Court does not have territorial jurisdiction over crimes,

32 ICC, Declaration Accepting the Jurisdiction of the ICC, 31 December 2014, http:// www.icc-cpi.int/iccdocs/PIDS/press/Palestine_A_12-3.pdf.

33 First information addressed to the OTP alleging war crimes by British armed forces in Iraq was not accepted. Previous Prosecutor Mr. Luis Moreno Ocampo decided not to open preliminary examination on the ground of non-sufficient gravity establishing the jurisdiction of the ICC, http://www.icc-cpi.int/NR/rdonlyres/04D143C8-19FB-466CAB77-4CDB2FDEBEF7 /143682/OTP_letter_to_senders_re_Iraq_9_February_2006.pdf 34 ICC, OTP, Statement 13/05/2014, http://www.icc-cpi.int/en_menus/icc/press\%20 and\%20media/press\%20releases/Pages/otp-statement-iraq-13-05-2014.aspx 
since Iraq and Syria are not member-states. ${ }^{35}$ On the other hand, the Court can establish personal jurisdiction, over the ISIS members from states - the members of the Statue (such as Jihadi John, for example) or through the referral by the UN Security Council. ${ }^{36}$ Possibility of the UN SC referral was discussed at its meeting on 27 March 2015. Meeting was initiated by the French Foreign Minister Laurent Fabius. Discussion at the meeting showed the lack of consent on whether a referral should/could concern only situation in one state or in two states (Iraq and Syria), does referral of the situation means exclusively referral of a situation in a state or it can also mean situation as a matter and even cases. ${ }^{37}$ Meeting did not provide final stance on whether and in what form to opt for referral.

Overviewing the presented novelties in the work of the ICC several, conclusions could be drawn. The first conclusion is that the ICC acts. It is recognized as a judicial forum. States as well as individuals, i.e. associations or NGO's do refer information to the Court. In the most general terms that indicates that the Court is accepted. At least it indicates that such a forum is needed. On the other hand, the examples of declarations submitted by Ukraine and Palestine do show another trend. It shows again eagerness to prosecute ex post facto. Such approach is typical for ad hoc courts and opposite to legally accurate jurisdiction pro futuro. Such a conclusion indicates that Court is still in need to uphold its presence and importance.

On the other hand it is inevitable to conclude that states tend to approach to the Court in periods of need. When situation occurred, crimes were perpetrated and states faced with its own incapability, they do recognize the ICC as the efficient forum. A stand towards this tendency could be pro if we still find that the Court is about to promote its very existence. However, if we believe that the Court is recognized as efficient, impartial organ then such a tendency should not be encouraged.

Whatever approach chosen, either pro or contra, it should be concluded that we are witnessing a specific expanding of the Courts jurisdiction.

35 ICC, OTP, Statement of the Prosecutor of the International Criminal Court, Fatou Bensouda, on the alleged crimes committed by ISIS, Statement : 08/04/2015, http:// www.icc-cpi.int/en_menus/icc/press\%20and\%20media/press\%20releases/Pages/otpstat-08-04-2015-1.aspx

36 The Prosecutor stated: "The information gathered indicates that several thousand foreign fighters have joined the ranks of ISIS in the past months alone, including significant numbers of State Party nationals from, inter alia, Tunisia, Jordan, France, the United Kingdom, Germany, Belgium, the Netherlands and Australia" - Ibid.

37 UN Security Council 7419 ${ }^{\text {th }}$ meeting, 27 March 2015, S/PV.7419 


\section{Conclusion}

International criminal courts architecture is not finalized. This is the reason that explains importance of the issues elaborated within this paper. It is the matter of the classical legal principle of stability and certainty that it should be clear and properly defined who can prosecute and in what legal forum. The best illustration of the issues elaborated within this paper is the attitude of ad hoc Tribunal for former Yugoslavia in the matter of crimes occurred on the territory of Kosovo and Albania. It provoked creation of yet another judicial body of an international/internationalized character. The mentioned example shows that expanding of the jurisdiction is more likely to provoke chaos than coherence. On the other hand, the examples from the domain of the International Criminal Court could be marked differently. It is true that expanding of jurisdiction, for the Court itself is more desirable in terms of membership. Yet again, the Court does not possess necessary authority and reputation in the international community, allowing it to refuse limited jurisdiction. Thus, when it comes to the ICC, it should be stated that limited jurisdiction and ad hoc arrangements with states are still welcomed. They should be understood as a mean of Court's promotion and strengthening. As for the main issue and focus of the paper, it should be concluded that the present model of expanding of the ICC's jurisdiction should be supported and treated as coherence.

\section{References}

1. Afagbegee A., The International Criminal Courts relation with Africa: An Unfair Bias?, Pan-African Voices for Freedom and Justice, 2014.

2. Bassiouni M.C., A Draft International Criminal Code and Draft Statute for an International Criminal Tribunal, Martinus Nijhoff Publishers, 1987.

3. Broomhall B., International Justice and International Criminal Court: Between Sovereignty and the Rule of Law, Oxford, 2003.

4. Cassese A., From Nuremberg to Rome: International Military Tribunals to the International Criminal Court, u: Antonio Cassese, Paola Gaeta, John R.W.D. Jones (eds.), The Rome Statute of the International Criminal Court: A Commentary, Volume I, Oxford University Press, 2002.

5. Dapčević Marković LJ., Međunarodni krivični tribunal, Bezbednost, God.38, br.6, 1996, pp.722-730.

6. Dicker R., The International Criminal Court and Double Standards of International Justice, u: Stahn C., The Law and Practice of the International Criminal Court, Oxford University Press, 2015. 
7. Herik L. van den, The Contribution of the Rwanda to the Development of International Law, Martinus Nijhoff Publishers, 2005.

8. Ivanišević B., The War Crimes Chamber in Bosnia and Herzegovina: From Hybrid to Domestic Court , International Center for Transitional Justice, 2008.

9. Katzenstein S., In the Shadow of Crisis: The Creation of International Courts in the Twentieth Century, Harvard International Law Journal, Vol. 55, number 1, 2014, pp. 151-178.

10. Murithi T., The African Union and the International Criminal Court: An Embattled Relationship?, Institute for Justice and Reconciliation, 2013, https://www.africaportal.org/dspace/articles/african-union-andinternational-criminal-court-embattled-relationship

11. Nouwen S.M.H., "Hybrid courts": The hybrid category of a new type of international criminal courts, Utrecht Law Review,Vol.2, Issue 2, 2006.

12. Ponte C. del, La caccia: Io e i criminali di guerra, 2008 - http://en.wikipedia. org/wiki/The_Hunt:_Me_and_War_criminals

13. Sadat L.N., The International Criminal Court and the Transformation of International Law, in: Sadat L.N., Scharf M.P. (ed.), The Theory and Practice of International Criminal Law. Essays in Honour of M. Cherif Bassiouni, Martinus Nijhoff Publishers, 2008.

14. Schabas W.A., The UN International Criminal Tribunals - the former Yugoslavia, Rwanda and Sierra Leone, Cambridge University Press, 2006.

15. Schabas W.A., An Introduction to the International Criminal Court, Cambridge University Press, 2001.

16. Sunga L.S., The Emerging System of International Criminal Law: Developments in Codification and Implementation, Kluwer Law International, 1997.

17. Šurlan T., Transplantacija i trgovina ljudskim organima, tkivima i ćelijama - međunarodnopravni i nacionalnopravni normativni okvir, Fondacija Centar za javno pravo, http://www.fcjp.ba/templates/ja_avian_ii_d/ images/green/Tijana_Surlan.pdf

18. Surlan T., Influence of the Security Council on the Jurisdiction of the International Criminal Court and Possible Revision of the Article 16, in: Thematic Conference Proceedings of International Signifacance, Archibald Reiss Days, Vol. II, Belgrade, 2011, pp. 469-480.

19. Jović Ž., Mirovne misije UN i globalizacija, Bezbednost, Godina LVI, br. 1,2014, str.104-121.

20. Šurlan T., Princip ne bis in idem u Rimskom Statutu, NBP - Nauka, bezbednost policija, Vol. IX, No. 1, 2004, pp. 93-115. 
21. Šurlan T., Princip univerzalne krivične nadležnosti, NBP - Nauka, bezbednost policija, Vol. 2011, XVI, No.2, str.101-116.

22. Šurlan T., Oduzimanje organa kao actus reus međunarodnih krivičnih dela, Strani pravni život, 2/2014, pp.57-76.

23. Шурлан Т., Место Гаагских конференций (1899 и 1907 гг.) в развитии международного права и международных отношений, у: Смолина М.Б., Залеский К.А. (ред.), Накануне Великой войны: Россия и мир Сборник докладов и статей, Москва 2014, pp. 119-141.

\title{
PROŠIRENJE NADLEŽNOSTI MEĐUNARODNIH KRIVIČNIH SUDOVA: KOHERENTNOST ILI HAOS
}

\author{
Tijana Šurlan \\ Kriminalističko-policijska akademija, Beograd
}

Sažetak: Naslovljeni rad bavi se jednim novim fenomenom fenomenom proširivanja nadležnosti postojećih međunarodnih krivičnih sudova. Trenutno postoje dva ad hoc Međunarodna krivična tribunala, jedan stalni Međunarodni krivični sud i nekoliko hibridnih i internacionalizovanih međunarodnih krivičnih sudova. Ad hoctribunali trenutno su u fazi transformacije i prenošenja nadležnosti na UN Mehanizam za međunarodne krivične tribunale. Što se tiče stalnog Međunarodnog krivičnog suda, poželjan model proširivanja domašaja rada ovog Suda je kroz uvećanje država članica njegovog Statuta. No što se trenutno dešava je uvećavanje nadležnosti nekim drugačijim pravnim sredstvima, a ne uobičajenim i poželjnim članstvom u Sudu. Opšta tendencija u domenu međunarodnog krivičnog pravosuđa ogleda se u uvećanom kreiranju novih sudova, iako ta tendencija nije ubedljivo prihvaćena kao dobrodošla. Umnožavanje broja međunarodnih sudova, sa istom ratione materiae nadležnošću, jasno je da može dovesti do preklapanja u postupanju. S druge strane dovodi do proširivanja nadležnosti po drugim principima određivanja nadležnosti. Stoga fokus ovog rada i jeste usmeren ka razrešenju dileme - da li opisana situacija kreira stanje koherentnosti ili haosa.

Ključne reči: nadležnost, ad hoc Međunarodni krivični tribunal za bivšu Jugoslaviju, ad hoc Tribunal za Ruandu, UN Mehanizam za međunarodne krivične tribunale, Međunarodni krivični sud. 